\title{
INDEX TO VOLUME 7 (1969)
}

\section{ARTICLES}

'Africa-the time of choice', by V. C. Vigand, I, 35-46

'Agricultural Development in the Ivory Coast and Ghana', by Jean M. Due, $4,637-60$

Allen, V. L., 'The Study of African Trade Unionism', 2, 289-307

'American Political Science and African Politics', by William G. Fleming, 3, $495^{-5} 5^{\text {I2 }}$

Ashford, Douglas E., 'The Politics of Rural Mobilisation in North Africa', 2, $187-202$

'Crude Private Neo-Imperialism: a new pattern in Africa', by Sayre P. Schatz, $4,677-88$

DAY, JohN, 'Southern Rhodesian African Nationalists and the I96I Constitution', 2, $22 \mathrm{I}-47$

Due, Jean M., 'Agricultural Development in the Ivory Coast and Ghana', 4, $637-60$

'Economic Co-operation in East Africa', by Donald C. Mead, 2, 277-87

'Elections and Coups in Sierra Leone, 1967', by Humphrey J. Fisher, 4, 6 I $1-36$

'Ethnic Inequalities in Kenya', by Donald Rothchild, 4, 689-7 I I

'European Exploration and Africa's Self-discovery', by Ali A. Mazrui, 4, $66 \mathrm{I}-76$

Fisher, Humphrey J., 'Elections and Coups in Sierra Leone, ig67', 4, 6 I $1-3^{6}$

Fleming, William G., 'American Political Science and African Politics', 3, $495^{-5} 5^{12}$

'The Future of the Company in Tanzanian Development', by Alan R. Roe, I, $47-67$

'Gandhi in South Africa', by Paul F. Power, 3, 44, $1-56$

'Ghana, the Congo, and the United Nations', by Jitendra Mohan, 3, $369-406$

Heitman, George, 'Libya: an analysis of the oil economy', 2, 249-63

Hopkins, Nicholas S., 'Port Harcourt: Ibo politics in microcosm', 3, $457-68$

Hulec, Otakar, 'Some Aspects of the rg3os Depression in Rhodesia', I, 95-105

'International Trade and the Developing Countries', by J. F. Rweyemamu, 2, 203-19

Kimble, Helen, 'On the Teaching of Economics in Africa, 4, 713-42

Kraus, Jon, 'On the Politics of Nationalism and Social Change in Ghana', I, IO7-30

Langley, J. Ayo, 'Pan-Africanism in Paris, 1924-36', I, 69-94

'Libya: an analysis of the oil economy', by George Heitman, 2, 249-63 
Mazrui, Ali A., 'European Exploration and Africa's Self-discovery', 4, $66 I-76$

McKinnell, Robert, 'Sanctions and the Economy of Rhodesia', 4, 559-8I Mead, Donald C., 'Economic Co-operation in East Africa', 2, 277-87

Mohan, Jitendra, 'Ghana, the Congo, and the United Nations', 3, 369-406 'The N.C.N.C. and Ethnic Unions in Biafra', by Audrey Chapman Smock, I, 2 I -34

'On the Politics of Nationalism and Social Change in Ghana', by Jon Kraus, $1,107-30$

'On the Teaching of Economics in Africa', by Helen Kimble, 4, 713-42

'The Origins of African Political Consciousness in South Africa', by Peter Walshe, 4, 583-610

'Pan-Africanism in Paris, 1924-36', by J. Ayo Langley, I, 69-94

'Political Competition and One-Party Dominance in Zambia', by Thomas Rasmussen, 3, 407-24

'The Politics of Rural Mobilisation in North Africa', by Douglas E. Ashford, 2, $187-202$

'The Politics of Security: South Africa under Verwoerd, $196 \mathrm{I}-6$ ', by Newell M. Stultz, I, 3-20

'Port Harcourt: Ibo politics in microcosm', by Howard E. Wolpe, 3, 469-94

'The Portuguese Army in Angola', by Douglas L. Wheeler, 3, 44I-56

Power, Paul, F., 'Gandhi in South Africa', 3, 441-56

Rasmussen, Thomas, 'Political Competition and One-Party Dominance in Zambia', 3, 407-24

Roe, Alan R., 'The Future of the Company in Tanzanian Development', 1, $47-67$

Rothchild, Donald, 'Ethnic Inequalities in Kenya', 4, 689-7 I I

Rweyemamu, J. F., 'International Trade and the Developing Countries', 2, 203-19

'Sanctions and the Economy of Rhodesia', by Robert McKinnell, 4, 559-81

Sahatz, SAyre P., 'Crude Private Neo-Imperialism: a new pattern in Africa', pp. 677-88

Smogk, Audrey Ghapman, 'The N.C.N.C. and Ethnic Unions in Biafra', I, 2 I-34

'Socialism and Social Change in Rural Mali', by Nicholas S. Hopkins, 3, $457-68$

'Some Aspects of the I93os Depression in Rhodesia', by Otakar Hulec, I, 95-I 05

'Southern Rhodesian African Nationalists and the I96r Constitution', by John Day, 2, 22 I -47

'The Study of African Trade Unionism', by V. L. Allen, 2, 289-307

Stultz, Newell M., 'The Politics of Security: South Africa under Verwoerd, I 96 I $-6^{\prime}$, I, 3-20

'Urbanisation and the Solidarity of Afrikaner Nationalism', by David Welsh, 2, 265-76

Vigand, V. C., 'Africa-the time of choice', I, 35-46

Walshe, Peter, 'The Origins of African Political Consciousness in South Africa', 4, 583-6ro 
Welsh, DAvid, 'Urbanisation and the Solidarity of Afrikaner Nationalism', $2,265-76$

Wheeler, Douglas L., 'The Portuguese Army in Angola', 3, 425-40

Wolpe, Howard E., 'Port Harcourt: Ibo politics in microcosm', 3, 469-94

\section{AFRICANA}

African Studies in Colorado, by Ragaei el Mallakh, 3, 516-1 7

An African Village in Transition: research into behaviour patterns, by George $H$. and Nancy W. Axinn, 3, 527-34

Ali, Shanti Sadie, The Indian Council for Africa, 3, 523-24

Annual Meeting of the (American) African Studies Association, by Helen Kitchen, 2, 319-22

Axinn, George H. and Nancy W., An African Village in Transition : research into behaviour patterns, 3, 527-34

Basic Bibliography on Madagascar, by Jean Valette, 2, 337-42

Bax, Margaret, Twentieth Anniversary Conference of the Program of African Studies, Northwestern University, Evanston, I, I35-6

BetTs, T. F., Zonal Rural Development in Africa, I, 149-53

Bouvet, Janine, El Congreso Hispano-Africano de Cooperacion y Comercio, $3,526-7$

Business Analysis for Africa, New York, by Paul Semonin, 3, 525-6

Callaway, Arghibald, Inter-Regional Seminar on National Youth Service Programmes, I, I42-4

Le Centre de hautes études sur l'Afrique et l'Asie modernes, Paris, by J.-C. Froelich, 3, 520-22

Centre de perfectionnement pour le développement et la coopération économique et technique, Paris, by Daniel Pepy, I, I 3 I-5

Coleman, James S., Institute for Development Studies, University College, Nairobi, 2, 31 7-I9

Colorado, African Studies in, by Ragaei el Mallakh, 3, 516-1 7

Conference of Directors of African Schools and Institutes of Public Administration, by G. E. Mills, I, 145-7

Conference on Inter-University Co-operation in the Promotion of Development, by Louis Sabourin, I, I44-5

El Congreso Hispano-Africano de Cooperacion y Comercio, by Janine Bouvet, 3, 526-7

Costanzo, Giuseppe A., Italian Studies on Africa, 2, 309-I 7

Growder, Mrahael, Institute of African Studies, Ife, 3, 513-I 5

Deutsches Institut für Afrika-Forschung, Hamburg, by Wolfgang Heidelberg, $3,5^{18-20}$

Ewing, A. F., Reflections from Afar on the Ninth Session of the U.N. Economic Commission for Africa, 2, 330-4

Fifteenth Session of the U.N.E.S.C.O. General Conference, by Casely M. O. Mate, I, I $3^{6-9}$

Froelich, J.-G., Le Centre de hautes études sur l'Afrique et l'Asie modernes, Paris, 3, 520-2 
de Gregori, Thomas, Symposium on Technology as a Social Process in Africa, 2, 322-24

Hamburg, Deutsches Institut für Afrika-Forschung, by Wolfgang Heidelberg, 3, 518-20

Heidelberg, Wolfgang, Deutsches Institut für Afrika-Forschung, Hamburg, 3, 5I8-20

Ife, Institute of African Studies, by Michael Crowder, 3, 513-I5

The Indian Council for Africa, by Shanti Sadiq Ali, 3, 523-4

Institute for Development Studies, University College, Nairobi, by James $\mathbf{S}$. Coleman, 2, 3 1 7-19

Institute of African Studies, Ife, by Michael Crowder, 3, 5I $3^{-15}$

Inter-Regional Seminar on National Youth Service Programmes, by Archibald Callaway, I, I 42-54

Italian Studies on Africa, by Giuseppe A. Costanzo, 2, 309-1 7

Judet, P., Seminar on the Use of Mass Media for Social Education in Urban Areas of Africa, 2, 325-30

Kitchen, Helen, Annual Meeting of the (American) African Studies Association, 2, 319-22

Madagascar, Basic Bibliography on, by Jean Valette, 2, 337-42

el Mallakh, Ragaei, African Studies in Colorado, 3, 516-I 7

Mate, Casely M. O., Fifteenth Session of the U.N.E.S.C.O. General Conference, 1, I $36-9$

Mrlus, G. E., Conference of Directors of African Schools and Institutes of Public Administration, I, I45-7

Nairobi, Institute for Development Studies, University College, by James S. Coleman, 2, 3 I 7-I9

New York, Business Analysis for Africa, by Paul Semonin, 3, 525-6

Northwestern University, Evanston, Twentieth Anniversary Conference of the Program of African Studies, by Margaret Bax, I, $135^{-6}$

Nursey-Bray, P. F., University of East Africa Social Science Conference, 2, 324-5

Ouko, Robert J., Seminar on Improving the Effectiveness of the Public Services, I, I 39-42

Packard, Philip C., Research Notes on Network Analysis, I, I 47-9

Paris, Le Centre de hautes études sur l'Afrique et l'Asie modernes, by J.-C. Froelich, 3, 520-2

Paris, Centre de perfectionnement pour le développement et la coopération économique et technique, by Daniel Pepy, I, I $31-5$

Pepy, Daniel, Centre de perfectionnement pour le développement et la coopération économique et technique, I, I 3 I-5

Reflections from Afar on the Ninth Session of the U.N. Economic Commission for Africa, by A. F. Ewing, 2, 330-4

Research Notes on Network Analysis, by Philip C. Packard, I, I 47-9

Sabourin, Louis, Conference on Inter-University Co-operation in the Promotion of Development, I, I 44-5

Seminar on Improving the Effectiveness of the Public Services, by Robert J. Ouko, I, I 39-42 
Seminar on the Use of Mass Media for Social Education in Urban Areas of Africa, by P. Judet, 2, 325-30

Semonin, Paul, Business Analysis for Africa, New York, 3, 525-6

Studying Ethnic Consciousness in Tropical Africa, by René V. L. Wadlow, 2, 334-7

Symposium on Technology as a Social Process in Africa, by Thomas R. de Gregori, 2, 322-4

Twentieth Anniversary Conference of the Program of African Studies, Northwestern University, Evanston, by Margaret Bax, I, I 35-6

University of East Africa Social Science Conference, by P. F. Nursey-Bray, $2,324-5$

VALETTE, JeAn, Basic Bibliography on Madagascar, 2, 337-42

Wadlow, René V. L., Studying Ethnic Consciousness in Tropical Africa, 2, 334-7

Zonal Rural Development in Africa, by T. F. Betts, I, I49-53

\section{REVIEWS}

AdedejI, Adebayo (ed.), Nigerian Administration and its Political Setting, reviewed by Oluwadare Aguda, 2, 349-5I

Adloff, Righard, and Thompson, Virginia, Djibouti and the Horn of Africa, reviewed by Yousuf Duhul, 4, 670-1

Africa and United States Policy by Rupert Emerson, reviewed by Richard D. Ralston, 3, 535-6

Africa Contemporary Record: annual survey and documents, I968-69 written and compiled by Colin Legum and John Drysdale, reviewed by Yash Tandon, 4, 743-5

African Betrayal by Charles E. and Alice B. Darlington, reviewed by John S. Saul, 4, 755-6

African Renaissance by Leonard Barnes, reviewed by Hamish Millar-Craig, 2, $343-5$

African Trade Unions by Ioan Davies, reviewed by V. L. Allen, 2, 299-305 passim

African Zion: the attempt to establish a Jewish colony in the East Africa Protectorate, 1903-5 by Robert G. Weisbord, reviewed by Ralph E. S. Tanner, I, I 72-3

L'Afrique commerce avec l'Afrique by Bernard Vinay, reviewed by Reginald $\mathrm{H}$. Green, 4, 747-9

Aguda, Oluwadare, review of Nigeria by Walter Schwarz, and of Nigerian Administration and its Political Setting edited by Adebayo Adedeji, 2, 349-5I

Allen, V. L., review of Politics in an Urban African Community by A. L. Epstein, of Labour in the Tropical Territories of the Commonwealth by B. G. Roberts, of Collective Bargaining in African Countries by B. C. Roberts and L. Greyfie de Bellecombe, of The Development of Trade Unions in Uganda by Roger Scott, of Unions in Emerging Societies by S. C. Sufrin, of African Trade Unions by Ioan Davies, and of Trade Unionism in Africa by Jean Meynaud and Anisse Salah-Bey, 2, 290-307 
Alpers, Edward A., review of Portugal and the Scramble for Africa, 1875-1891 by Eric Axelson, of Portugal and Africa, 1815-1910: a study in uneconomic imperialism by R. J. Hammond, and of Brazil and Africa by José Honorio Rodrigues, 3, 544-6

Amin, SAmir, L'Economie du Maghreb, Vols. I and $I I$, reviewed by Frederick F. Clairmonte, 2, 353-7

Ankomah, Kofi, review of Unity or Poverty? by Reginald H. Green and Ann Seidman, I, I 59-6 I

Apropos of Africa: sentiments of American Negro leaders on Africa from the 1800 s to the 1950s compiled by Adelaide Cromwell Hill and Martin Kilson, reviewed by K. A. B. Jones-Quartey, $4,763-6$

Apter, David, Ghana in Transition, reviewed by Jon Kraus, I, I07-30 passim Asian Drama, Vols. I, II, and III by Gunnar Myrdal, reviewed by A. F. Ewing, I, $165-8$

Ashford, Douglas E., National Development and Local Reform: political participation in Morocco, Tunisia, and Pakistan, reviewed by Wouter Teller, 2, $35 \mathrm{I}-3$

Austin, Dennis, Politics in Ghana, 1946-196o, reviewed by Jon Kraus, I, I07-I o passim

Austruy, Jacques, Le Scandale du développement, reviewed by E. C. Dommen, 3, 54 I-2

Awe, B., Lloyd, P. C., and Mabogunje, A. L. (eds.), The City of Ibadan, reviewed by Edward W. Soja, 2, 357-9

Axelson, Eric, Portugal and the Scramble for Africa, 1875-1891, reviewed by Edward A. Alpers, 3, 544-6

BAER, GEORge W., review of Burden of Empire: an appraisal of western colonialism in Africa south of the Sahara by L. H. Gann and Peter Duignan, 1, 168-70

Ballard, John A., review of The British in Northern Nigeria by Robert Heussler, of Colonial Cadet in Nigeria by John Smith, and of Parties and Politics in Northern Nigeria by B. J. Dudley, 4, 756-8

Barnes, Leonard, African Renaissance, reviewed by Hamish Millar-Craig, 2, $343-5$

BARRetT, David B., Schism and Renewal in Africa: an analysis of six thousand contemporary religious movements, reviewed by William $\mathrm{H}$. Crane, 2, $359-6$ I

Beauregard, Erving E., review of The Cape Colour Question: a historical survey by W. M. Macmillan, 3, 547-8

de Bellecombe, L. Greyfie, and Roberts, B. C., Collective Bargaining in African Countries, reviewed by V. L. Allen, 2, 296-7

Bing, Geoffrey, Reap the Whirlwind: an account of Kwame Nkrumah's Ghana from 1950 to 1966 , reviewed by Jon Kraus, I, 107-30 passim

Birmingham, Walter, Neustadt, I., and Omaboe, E. N. (eds.), A Study of Contemporary Ghana, Vol. II, Some Aspects of Social Structure, reviewed by R. K. Som, 4, 750-2

The Black Man in Search of Power: a survey of the black revolution across the world by The Times News Team, reviewed by Locksley Edmondson, I, I 55-9

Black Power and Urban Unrest: creative possibilities by Nathan Wright, reviewed by Locksley Edmondson, I, I 55-9 
Black Power: the politics of liberation in America by Stokely Carmichael and Charles V. Hamilton, reviewed by Locksley Edmondson, I, I 55-9

DE BliJ, Harm J., Mombasa: an African city, reviewed by Edward W. Soja, 2, 357-9

Boehm, Walter W., review of The Demography of Tropical Africa by William Brass $e$ al., of Population and Political Systems in Tropical Africa by Robert F. Stevenson, and of The Population of Tropical Africa edited by J. C. Caldwell and Chuchuka Okonjo, I, I 76-8

Bognar, Jozsef, The Future Place and Role of the Developing Countries in the World Economy, and Priorities in Scientific Research and in the Application of Science to Economic Development, reviewed by Reginald H. Green, 3, 537 Brass, William, et al., The Demography of Tropical Africa, reviewed by Walter W. Boehm, I, $176-8$

Brazil and Africa by José Honorio Rodrigues, reviewed by Edward A. Alpers, $3,542-4$

Bretton, Henry, The Rise and Fall of Kwame Nkrumah, reviewed by Jon Kraus, I, 107-30 passim

Britain and Germany in Africa: imperial rivalry and colonial rule edited by Prosser Gifford and Wm. Roger Louis, reviewed by Fred L. Hadsel, 3, 542-3

The British in Northern Nigeria by Robert Heussler, reviewed by John A. Ballard, 4, 456-8

Brown, Richard, review of Revolt in Southern Rhodesia, $1896-7$ by T. O. Ranger, I, I $70-2$

Burden of Empire: an appraisal of western colonialism in Africa south of the Sahara by L. H. Gann and Peter Duignan, reviewed by George W. Baer, I, I $68-70$

Galdwell, J. C., and Okonjo, Chughuka (eds.), The Population of Tropical Africa, reviewed by Walter W. Boehm, 1 , I $76-8$

Campagnes militaires au Sud-Angola $\left(1885^{-1915)}\right.$ by René Pélissier, reviewed by Douglas L. Wheeler, 4, 759-6o

The Cape Colour Question: a historical survey by W. M. Macmillan, reviewed by Erving E. Beauregard, 3, 547-8

Carmichael, Stokely, and Hamilton, Charles V., Black Power: the politics of liberation in America, reviewed by Locksley Edmondson, I, I 55-9

The Challenge of Development: report of an East African conference, reviewed by Rowena M. Lawson, 2, 347-9

Chidzero, Bernard T. G., review of Industry in Africa by A. F. Ewing, I, I6I-3

The City of Ibadan edited by P. C. Lloyd, A. L. Mabogunje, and B. Awe, reviewed by Edward W. Soja, 2, 357-9

Glairmonte, Frederick F., review of L'Economie du Maghreb, Vols. I and II by Samir Amin, and of Le Maghreb entre les mythes: l'économie nord-africaine depuis l'indépendance by André Tiano, 2, 353-7

Collective Bargaining in African Countries by B. C. Roberts and L. Greyfie de Bellecombe, reviewed by V. L. Allen, 2, 296-7

Colonial Cadet in Nigeria by John Smith, reviewed by John A. Ballard, 4, 756-8

de Craemer, Willy, and Fox, Renée, The Emerging Physician, reviewed by Jens Erik Steenstrup, I, I 73-6 
Crane, William H., review of Schism and Renewal in Africa: an analysis of six thousand contemporary religious movements by David B. Barrett, 2, 359-6 I

Creating Political Order: the party-states of West Africa by Aristide Zolberg, reviewed by Jon Kraus, I, 107-30 passim

Crowder, Michaes, West Africa under Colonial Rule, reviewed by Fred L. Hadsel, 3, 542-3

Currie, Jean I., and Whetham, Edith H., The Economics of African Countries, reviewed by Helen Kimble, 4, 734-7

Dams in Africa: an inter-disciplinary study of man-made lakes in Africa edited by W. M. Warren and N. Rubin, reviewed by Rowena M. Lawson, 2, 347-9

Darlington, Charles E. and Alice B., African Betrayal, reviewed by John S. Saul, $4,755^{-6}$

Davies, IoAn, African Trade Unions, reviewed by V. L. Allen, 2, 299-305 passim

The Demography of Tropical Africa by William Brass et al., reviewed by Walter W. Boehm, I, I $76-8$

The Development of Education in Africa and its Problems by Péter Mandi, reviewed by Reginald H. Green, 3, 537

The Development of Trade Unions in Uganda by Roger Scott, reviewed by V. L. Allen, 2, 292-302 passim

Dinwiddy, Caroline, Elementary Mathematics for Economists, reviewed by Dudley Kessel, 2, 365-6

Dipoko, Mbella SonNe, review of France and the Africans, 1944-196o by Edward Mortimer, and of French-speaking Africa since Independence by Guy de Lusignan, 4, 752-5

Dixon-Fyle, R. S., review of The Economic System of Sierra Leone by R. G. Saylor, I, I 63-5

Djibouti and the Horn of Africa by Virginia Thompson and Richard Adloff, reviewed by Yousuf Duhul, 4, 760-I

Dommen, Bridget, review of Proceedings of the Eighth International Conference of the International Planned Parenthood Federation, and of The Role of Family Planning in African Development: proceedings of an African regional seminar, 2, 363-5

Dommen, E. C., review of Le Scandale du développement by Jacques Austruy, 3, $54 \mathrm{I}-2$

Dotson, Floyd and Lillian O., The Indian Minority of Zambia, Rhodesia, and Malawi, reviewed by Sukhi Singh, $4,762-3$

Drysdale, John, and Legum, Colin, Africa Contemporary Record: annual survey and documents, 1968-1969, reviewed by Yash Tandon, 4, 743-5

Dudley, B. J., Parties and Politics in Northern Nigeria, reviewed by John A. Ballard, $4,75^{6-8}$

Duhul, Yousuf, review of Djibouti and the Horn of Africa by Virginia Thompson and Richard Adloff, 4, 760-I

Duignan, Peter, and Gann, L. H., Burden of Empire: an appraisal of western colonialism in Africa south of the Sahara, reviewed by George W. Baer, I, I68-70

Economic Development and Planning in Egypt by Magdi M. El-Kammash, reviewed by Mustapha Nour, 3, 55 $1-3$ 
An Economics Textbook for Africa by Ann Seidman, reviewed by Helen Kimble, $4,737-41$

The Economics of African Countries by Edith H. Whetman and Jean I. Currie, reviewed by Helen Kimble 4, 734-7

The Economic System of Sierra Leone by R. G. Saylor, reviewed by R. S. DixonFyle, I, I63-5

L'Economie du Maghreb, Vols. I and II by Samir Amin, reviewed by Frederick F. Clairmonte, 2, 353-7

EDMondson, LocksLey, review of Black Power: the politics of liberation in America by Stokely Carmichael and Charles V. Hamilton, of Black Power and Urban Unrest: creative possibilities by Nathan Wright, of The Crisis of the Negro Intellectual from its Origins to the Present by Harold Cruse, and of The Black Man in Search of Power: a survey of the black revolution across the world by The Times News Team, I, I 55-9

The Effects of Economic Development on Traditional Political Systems in Africa South of the Sahara by John Middleton, reviewed by Wieland W. Jaeger, 4, 749-50

Egypt Since the Revolution edited by P. J. Vatikiotis, reviewed by Mustapha Nour, $3,55^{1-3}$

Elementary Mathematics for Economists by Caroline Dinwiddy, reviewed by Dudley Kessel, 2, 365-6

EL-Kammash, Magdi M., Economic Development and Planning in Egypt, reviewed by Mustapha Nour, 3, 55I-3

The Emerging Physician by Willy de Craemer and Renée C. Fox, reviewed by Jens Erik Steenstrup, I, I 73-6

Emerson, Rupert, Africa and United States Policy, reviewed by Richard D. Ralston, 3, 534-6

Emmerson, Donald K., Students and Politics in Developing Nations, reviewed by Linda Lowenstein, 4, 746-7

Epstein, A. L., Politics in an Urban African Community, reviewed by V. L. Allen, 2, 293-303 passim

Ewing, A. F., Industry in Africa, reviewed by Bernard T. G. Chidzero, I, I6I-3 - review of Asian Drama, Vols. I, II, and III by Gunnar Myrdal, I, I65-8

FItch, BoB, and Oppenheimer, MARY, Ghana: end of an illusion, reviewed by Jon Kraus, I, I07-30 passim

Fox, Renée C., and de Craemer, Willy, The Emerging Physician, reviewed by Jens Erik Steenstrup, I, I 73-6

France and the Africans, 1944-1960 by Edward Mortimer, reviewed by Mbella Sonne Dipoko, 4, 752-5

French-speaking Africa since Independence by Guy de Lusignan, reviewed by Mbella Sonne Dipoko, 4, 752-5

The Future Place and Role of the Developing Countries in the World Economy by Jozsef Bognar, reviewed by Reginald H. Green, 3, 537

GANn, L. H., and Duignan, PETER, Burden of Empire: an appraisal of western colonialism in Africa south of the Sahara, reviewed by George W. Baer, I, I68-70

The Geography of Modernization in Kenya by Edward W. Soja, reviewed by Dennis A. Lury, $3,54^{8-50}$

Ghana: end of an illusion by Bob Fitch and Mary Oppenheimer, reviewed by Jon Kraus, 1, 107-30 passim 
Ghana in Transition by David Apter, reviewed by Jon Kraus, I, 107-30 passim Grfford, Prosser, and Louis, WM. Roger (eds.), Britain and Germany in Africa: imperial rivalry and colonial rule, reviewed by Fred L. Hadsel, 3, 542-3

Gordenker, Leon, The U.N. Secretary-General and the Maintenance of Peace, reviewed by Yash Tandon, 2, 345-7

Great Cairo: mother of the world by Desmond Stewart, reviewed by Mustapha Nour, 3, $55^{\mathrm{I}-3}$

Green, Reginald H., review of Studies on Developing Countries: Nos 1, 2, 3, 11 , 12, 16, and 19 by J. Bognar, P. Mandi, P. Streeten, T. Szentes, and E. Kemenes, 3, 536-9

- review of L'Afrique commerce avec l'Afrique by Bernard Vinay, 4, 747-9

Green, Reginald H., and Seidman, Ann, Unity or Poverty?, reviewed by Kofi Ankomah, I, I59-6I

HAdSEL, FRed L., review of Britain and Germany in Africa: imperial rivalry and colonial rule edited by Prosser Gifford and Wm. Roger Louis, and of West Africa under Colonial Rule by Michael Crowder, 3, 542-3

Hamilton, Gharles V., and Garmichael, Stokely, Black Power: the palitics of liberation in America, reviewed by Locksley Edmondson, I. I55-9

Hammond, R. J., Portugal and Africa, 1875-1891: a study in uneconomic imperialism, reviewed by Edward A. Alpers, 3, 544-6

Hance, William A. (ed.), Southern Africa and the United States, reviewed by Richard D. Ralston, 3, 535-6

Heussler, Robert, The British in Northern Nigeria, reviewed by John A. Ballard, $4,756-8$

Hill, Adelaide Cromwell, and Kilson, Martin, Apropos of Africa: sentiments of American Negro leaders on Africa from the 1800 s to the 1950s, reviewed by K. A. B. Jones-Quartey, 4, 763-6

$A$ History of the Asians in East Africa c. 1886 to 1945 by J. S. Mangat, reviewed by Sukhi Singh, 4, 672-3

A History of $\mathcal{N} e 0-$ African Literature by Janheinz Jahn, reviewed by Abiola Irele, $3,553-6$

Hodder, B. W., Economic Development in the Tropics, reviewed by Rowena $\mathbf{M}$. Lawson, 2, 347-9

The Indian Minority of Zambia, Rhodesia, and Malawi by Floyd and Lillian O. Dotson, reviewed by Sukhi Singh, 4, 762-3

The Indians in Uganda by H. S. Morris, reviewed by Sukhi Singh, 4, 762-3

Industry in Africa by A. F. Ewing, reviewed by Bernard T. G. Chidzero, I, I $6 \mathrm{I}-3$

The Intermediaries: third parties in international crises by Oran R. Young, reviewed by Yash Tandon, 2, 345-7

Interpretations of Economic Underdevelopment by Tamas Szentes, reviewed by Reginald H. Green, 3, 538-9

An Introduction to Economics for East Africa by I. Livingstone and H. W. Ord, reviewed by Helen Kimble, 4, 737

Introduction to the Economy of Tropical Africa by Tames Szentes, reviewed by Reginald H. Green, 3, $53^{8}$

An Introduction to West African Economics by H.W. Ord and I. Livingstone, reviewed by Helen Kimble, 4, 737 
Irele, Abiola, review of A History of Neo-African Literature by Janheinz Jahn, 3, 553-6

Jaeger, Wieland W., review of The Effects of Economic Development on Traditional Political Systems in Africa South of the Sahara by John Middleton, 4, $749-50$

Jahn, Janheinz, A History of Neo-African Literature, reviewed by Abiola Irele, $3,553-6$

Jones-Quartey, K. A. B., review of Apropos of Africa: sentiments of American Negro leaders on Africa from the 1800 s to the 1950 s compiled by Adelaide Cromwell Hill and Martin Kilson, 4, 763-6

Kemenes, Egon, The Reform of the International Monetary System and the Developing Countries, reviewed by Reginald H. Green, 3, 537

KESSEL, DudLEY, review of Elementary Mathematics for Economists by Caroline Dinwiddy, 2, 365-6

Kilson, Martin, and Hill, Adelaide Cromwell, Apropos of Africa: sentiments of American $N$ egro leaders on Africa from the 1800 s to the 1950s, reviewed by K. A. B. Jones-Quartey, 4, 763-6

Kimble, Helen, review of The Economics of African Countries by Edith $\mathbf{H}$. Whetham and Jean I. Currie, of An Economics Textbook for Africa by Ann Seidman, of $A n$ Introduction to Economics for East $A$ frica by I. Livingstone and H. W. Ord, and of An Introduction to West African Economics by H. W. Ord and I. Livingstone, 4, 734-4I

KIng, Maurice (ed.), Medical Care in Developing Countries, reviewed by Jens Erik Steenstrup, I, $173-6$

Kraus, Jon, review of Ghana in Transition by David Apter, of Politics in Ghana, 1946-6o by Dennis Austin, of The Rise and Fall of Kwame Nkrumah by Henry Bretton, of Ghana: end of an illusion by Bob Fitch and Mary Oppenheimer, of Reap the Whirlwind: an account of Kwame Nkrumah's Ghana from 1950 to 1966 by Geoffrey Bing, and of Creating Political Order: the party-states of West Africa by Aristide Zolberg, I, I07-30 passim

Labour in the Tropical Territories of the Commonwealth by B. C. Roberts, reviewed by V. L. Allen, 2, 296-3o6 passim

Land and Population Movements in Kenya by S. H. Ominde, reviewed by Dennis A. Lury, $3,548-5^{\circ}$

Lawson, Rowena M., review of Dams in Africa: an inter-disciplinary study of man-made lakes in Africa edited by W. M. Warren and N. Rubin, of The Challenge of Development: report of an East African conference, and of Economic Development in the Tropics by B. W. Hodder, 2, 347-9

Legum, Colin, and Drysdale, John, Africa Contemporary Record: annual survey and documents, 1968-1969, reviewed by Yash Tandon, 4, 743-5

Livingstone, I., and ORd, H. W., An Introduction to Economics for East Africa, reviewed by Helen Kimble, 4, 737

- An Introduction to West African Economics, reviewed by Helen Kimble, 4, 737

Lloyd, P. G., Mabogunje, A. L., and Awe, B. (eds.), The City of Ibadan, reviewed by Edward W. Soja, 2, 357-9

Louis, Wm. Roger, and Gifford, Prosser (eds.), Britain and Germany in Africa: imperial rivalry and colonial rule, reviewed by Fred L. Hadsel, 3, 542-4 
Lowenstein, Linda, review of Students and Politics in Developing Nations edited by Donald K. Emmerson, 4, 746-7

Lury, Dennis A., review of Land and Population Movements in Kenya by S. H. Ominde, and of The Geography of Modernization in Kenya by Edward W. Soja, 3, 548-50

DE Lusignan, GuY, French-speaking Africa since Independence, reviewed by Mbella Sonne Dipoko, 4, 752-5

Mabogunje, A. L., Lloyd, P. C., and Awe, B. (eds.), The City of Ibadan, reviewed by Edward W. Soja, 2, 357-9

Macmillan, W. M., The Cape Colour Question: a historical survey, reviewed by Erving E. Beauregard, 3, 547-8

Le Maghreb entre les mythes: l'économie nord-africaine depuis l'indépendance, by André Tiano, reviewed by Frederick F. Clairmonte, 2, 353-7

Malawi: a political and economic history by John G. Pike, reviewed by John McCracken, 3, 546-7

MANDI, PÉTER, The Development of Education in Africa and its Problems, reviewed by Reginald H. Green, 3, 537

Mangat, J. S., A History of the Asians in East Africa c. 1886 to 1945, reviewed by Sukhi Singh, 4, 762-3

Martin, Robert, review of Tanzania, Permanent Commission of Enquiry: Annual Report, 1966-67, I, I 78-83

McCracken, John, review of Malawi: a political and economic history by John G. Pike, 3, 546-7

Medical Care in Developing Countries edited by Maurice King, reviewed by Jens Erik Steenstrup, I, I 73-6

Meynaud, Jean, and Salah-Bey, Anisse, Trade Unionism in Africa, reviewed by V. L. Allen, 2, 299-305 passim

Middeton, John, The Effects of Economic Development on Traditional Political Systems in Africa South of the Sahara, reviewed by Wieland W. Jaeger, 4, $749-5^{\circ}$

Millar-Craig, Hamish, review of African Renaissance by Leonard Barnes, 2, $343-5$

Mombasa: an African city by Harm J. de Blij, reviewed by Edward W. Soja, 2, $357-9$

Morgan, W. T. W. (ed.), Nairobi: city and region, reviewed by Edward W. Soja, 2, 357-9

Morris, H. S., The Indians in Uganda, reviewed by Sukhi Singh, 4, 762-3

Mortimer, EdWARd, France and the Africans, 1944-1960, reviewed by Mbella Sonne Dipoko, 4, 752-5

Myrdal, Gunnar, Asian Drama, Vols. $I, I I$, and $I I I$, reviewed by A. F. Ewing, I, $165-8$

Nairobi: city and region edited by W. T. W. Morgan, reviewed by Edward W. Soja, 2, 357-9

National Development and Local Reform: political participation in Morocco, Tunisia, and Pakistan by Douglas E. Ashford, reviewed by Wouter Teller, 2, 35I-3

Nigeria by Walter Schwarz, reviewed by Oluwadare Aguda, 2, 349-5I

Nigerian Administration and its Political Setting edited by Adebayo Adedeji, reviewed by Oluwadare Aguda, 2, 349-5I 
Nour, Mustapha, review of Great Cairo: mother of the world by Desmond Stewart, of Economic Development and Planning in Egppt by Magdi M. El-Kammash, and of Egypt Since the Revolution edited by P.J.Vatikiotis, $3,55^{1-3}$

Obstacles to Development by Paul Streeten, reviewed by Reginald H. Green, 3, $53^{8}$ Okonjo, Ghuchuka, and Caldwell, J. C. (eds.), The Population of Tropical Africa, reviewed by Walter W. Boehm, I, $176-8$

Ominde, S. H., Land and Population Movements in Kenya, reviewed by Dennis A. Lury, 3, 548-50

Oppenheimer, MARy, and Fitch, BoB, Ghana: end of an illusion, reviewed by Jon Kraus, I, 107-30 passim

Ord, H. W., and Livingstone, I., An Introduction to Economics for East Africa, reviewed by Helen Kimble, 4, 737

An Introduction to West African Economics, reviewed by Helen Kimble, 4, 737

Parties and Politics in Northern Nigeria by B. J. Dudley, reviewed by John A. Ballard, 4, 756-8

Pélissier, René, Campagnes militaires au Sud-Angola (1885-1915), reviewed by Douglas L. Wheeler, 4, 759-6o

Pike, John G., Malawi: a political and economic history, reviewed by John McCracken, 3, 546-7

Plessz, Nicholas, Problems and Prospects of Economic Integration in West Africa, reviewed by Peter Robson, 3, 539-40

Politics in an Urban African Community by A. L. Epstein, reviewed by V. L. Allen, 2, 293-303 passim

Politics in Ghana, 1946-1950 by Dennis Austin, reviewed by Jon Kraus, I, I07-30 passim

Population and Political Systems in Tropical Africa by Robert F. Stevenson, reviewed by Walter W. Boehm, I, I 76-8

The Population of Tropical Africa edited by J. C. Caldwell and Chuchuka Okonjo, reviewed by Walter W. Boehm, I, I 76-8

Portugal and Africa, 1815-1910: a study in uneconomic imperialism by R. J. Hammond, reviewed by Edward A. Alpers, 3, 544-6

Portugal and the Scramble for Africa, $1875^{-1891}$ by Eric Axelson, reviewed by Edward A. Alpers, 3, 544-6

Priorities in Scientific Research and in the Application of Science to Economic Development by Jozsef Bognar, reviewed by Reginald H. Green, 3, 537

Problems and Prospects of Economic Integration in West Africa by Nicholas Plessz, reviewed by Peter Robson, 3, 539-40

Proceedings of the Eighth International Conference of the International Planned Parenthood Federation, reviewed by Bridget Dommen, 2, 363-5

Ralston, Righard D., review of Africa and United States Policy by Rupert Emerson, and of Southern Africa and the United States edited by William A. Hance, 3, 535-6

RANGer, T. O., Revolt in Southern Rhodesia, $1896-7$, reviewed by Richard Brown, I, I 70-2

Reap the Whirlwind: an account of Kwame Nkrumah's Ghana from $195^{\circ}$ to 1966 by Geoffrey Bing, reviewed by Jon Kraus, I, 107-30 passim 
The Reform of the International Monetary System and the Developing Countries by Egon Kemenes, reviewed by Reginald H. Green, 3, 537

Revolt in Southern Rhodesia, $1896-7$ by T. O. Ranger, reviewed by Richard Brown, I, I 70-2

The Rise and Fall of Kwame Nkrumah by Henry Bretton, reviewed by Jon Kraus, I, 107-30 passim

RoBerts, B. G., Labour in the Tropical Territories of the Commonwealth, reviewed by V. L. Allen, 2, 296-306 passim

Roberts, B. C., and de Bellecombe, L. Greyfie, Collective Bargaining in African Countries, reviewed by V. L. Allen, 2, 296-7

Robson, Peter, review of Problems and Prospects of Economic Integration in West Africa by Nicholas Plessz, 3, 539-40

Rodrigues, José Honorio, Brazil and Africa, reviewed by Edward A. Alpers, $3,544^{-6}$

The Role of Family Planning in African Development: proceedings of an African regional seminar, reviewed by Bridget Dommen, 2, 363-5

Rubin, N., and Warren, W. M. (eds.), Dams in Africa: an inter-disciplinary study of man-made lakes in Africa, reviewed by Rowena M. Lawson, 2, 347-9

Russell, Ruth B., The United Nations and United States Security Policy, reviewed by Yash Tandon, 2, 345-7

Salah-Bey, Anisse, and Meynaud, Jean, Trade Unionism in Africa, reviewed by V. L. Allen, 2, 299-305 passim

Saul, John S., review of African Betrayal by Charles E. and Alice B. Darlington, $4,755^{-6}$

SAYLOR, R. G., The Economic System of Sierra Leone, reviewed by R. S. DixonFyle, 1, I63-5

Le Scandale du développement by Jacques Austray, reviewed by E. G. Dommen, $541-2$

Schism and Renewal in Africa: an analysis of six thousand contemporary religious movements by David B. Barrett, reviewed by William H. Grane, 2, 359-6I

Schwarz, Walter, Nigeria, reviewed by Oluwadare Aguda, 2, 349-5 ${ }^{\mathrm{r}}$

Scott, Roger, The Development of Trade Unions in Uganda, reviewed by V. L. Allen, 2, 298-302 passim

Seidman, Ann, An Economics Textbook for Africa, reviewed by Helen Kimble, $4,737-4$ I

Seidman, Ann, and Green, Reginald, H., Unity or Poverty?, reviewed by Kofi Ankomah, 1, I 59-6I

Singh, Sukhi, review of The Indian Minority of Zambia, Rhodesia, and Malawi by Floyd and Lillian O. Dotson, of The Indians in Uganda by H. S. Morris, and of $A$ History of the Asians in East Africa c. 1886 to 1945 by J. S. Mangat, 4, 762-3

Sмiтн, John, Colonial Cadet in Nigeria, reviewed by John A. Ballard, 4, 756-8

Soja, Edward W., The Geography of Modernization in Kenya, reviewed by Dennis A. Lury, 3, 548-50 
Soja, Edward, W., review of The City of Ibadan edited by P. C. Lloyd, A. L. Mabogunje, and B. Awe, of Mombasa: an African City by Harm J. de Blij, and of Nairobi: city and region edited by W. T. W. Morgan, 2, $357-9$

Som, R. K., review of A Study of Contemporary Ghana, Vol. II, Some Aspects of Social Structure edited by Walter Birmingham, I. Neustadt, and E. N. Omaboe, $4,75^{\circ-2}$

Southern Africa and the United States edited by William A. Hance, reviewed by Richard C. Ralston, 3, 535-6

Steenstrup, Jens Erik, review of Medical Care in Developing Countries edited by Maurice King, and of The Emerging Physician by Willy de Craemer and Renée C. Fox, I, I 73-6

Stevenson, Robert F., Population and Political Systems in Tropical Africa, reviewed by Walter W. Boehm, I, I 76-8

Stewart, Desmond, Great Cairo: mother of the world, reviewed by Mustapha Nour, $3,55^{\mathrm{I}-3}$

Streeten, Paul, Obstacles to Development, reviewed by Reginald H. Green, $3,53^{8}$

Students and Politics in Developing Nations edited by Donald K. Emmerson, reviewed by Linda Lowenstein, $4,746-7$

Studies on Developing Countries: Nos. 1, 2, 3, 11, 12, 16, and 19 by J. Bognar, P. Mandi, P. Streeten, T. Szentes, and E. Kemenes, reviewed by Reginald H. Green, 3, 536-9

A Study of Contemporary Ghana, Vol. II, Some Aspects of Social Structure edited by Walter Birmingham, I. Neustadt, and E. N. Omaboe, reviewed by R. K. Som, 4, 750-2

Surrin, S. G., Unions in Emerging Societies, reviewed by V. L. Allen, 2, 298305 passim

SwaNTZ, Lloyd W., review of Transition in African Beliefs: traditional religion and Christian change-a study in Sukumaland, Tanzania by Ralph E.S. Tanner, 2, 36I-3

Szentes, Tamas, Introduction to the Economy of Tropical Africa and Interpretations of Economic Underdevelopment, reviewed by Reginald H. Green, 3, 538-9

TANDON, Yash, review of The U.N. Secretary-General and the Maintenance of Peace by Leon Gordenker, of The United Nations and United States Security Policy by Ruth B. Russell, of The Intermediaries: third parties in international crises by Oran R. Young, 2, 345-7

- review of Africa Contemporary Record: annual survey and documents, 1968-1969 written and compiled by Golin Legum and John Drysdale, 4, 743-5

TANNER, RALPH E. S., review of African Zion: the attempt to establish a Fewish colony in the East Africa Protectorate, 1903-5 by Robert G. Weisbord, I, I 72-3

- Transition in African Beliefs: traditional religion and Christian change-m a study in Sukumaland, Tanzania, reviewed by Lloyd W. Swantz, 2, $3^{6} \mathbf{I}-3$

Tanzania, Permanent Commission of Enquiry: Annual Report, 1966-67, reviewed by Robert Martin, I, I 78-83 
Teller, Wouter, review of National Development and Local Reform: political participation in Morocco, Tunisia, and Pakistan by Douglas E. Ashford, 2, $35^{\mathrm{I}-3}$

Thompson, Virginia, and Adloff, Richard, Djibouti and the Horn of Africa, reviewed by Yousuf Duhul, 4, 760-I

Tiano, André, Le Maghreb entre les mythes: l'économie nord-africaine depuis l'indépendence, reviewed by Frederick F. Clairmonte, 2, 353-7

The Times News Team, The Black Man in Search of Power: a survey of the black revolution across the world, reviewed by Locksley Edmondson, I, 155-9

Trade Unionism in Africa by Jean Meynaud and Anisse Salah-Bey, reviewed by V. L. Allen, 2, 299-305 passim

Transition in African Beliefs: traditional religion and Christian change-a study in Sukumaland, Tanzania by Ralph E. S. Tanner, reviewed by Lloyd W. Swantz, 2, 36I-3

Unions in Emerging Societies by S. G. Sufrin, reviewed by V. L. Allen, 2, 298306 passim

The United Nations and United States Security Policy by Ruth B. Russell, reviewed by Yash Tandon, 2, 345-7

The U.N. Secretary-General and the Maintenance of Peace by Leon Gordenker, reviewed by Yash Tandon, 2, 345-7

Unity or Poverty? by Reginald H. Green and Ann Seidman, reviewed by Kofi Ankomah, I, I59-6I

Vatikiotis, P. J. (ed.), Egypt Since the Revolution, reviewed by Mustapha Nour, $3,55^{\mathrm{I}-3}$

VINAy, Bernard, L'Afrique commerce avec l'Afrique, reviewed by Reginald H. Green, 4, 747-9

Warren, W. M., and Rubin, N. (eds.), Dams in Africa: an inter-disciplinary study of man-made lakes in Africa, reviewed by Rowena M. Lawson, 2, $347-9$

WeIsbord, Robert G., African Zion: the attempt to establish a Jewish colony in the East Africa Protectorate, 1903-5, reviewed by Ralph E. S. Tanner, I, I 72-3

West Africa under Colonial Rule by Michael Crowder, reviewed by Fred L. Hadsel, 3, 542-3

Wheeler, Douglas L., review of Campagnes militaires au Sud-Angola (18851915) by René Pélissier, 4, 759-6o

Whetham, Edith H., and Gurrie, Jean I., The Economics of African Countries, reviewed by Helen Kimble, 4, 734-7

Wright, Nathan, Black Power and Urban Unrest: creative possibilities, reviewed by Locksley Edmondson, I, I 55-9

Young, ORAN R., The Intermediaries: third parties in international crises, reviewed by Yash Tandon, 2, 345-7

Zolberg, Aristide, Creating Political Order: the party-states of West Africa, reviewed by Jon Kraus, I, I07-30 passim 


\section{EDUCATION SINCE UHURU}

\section{The Schools of Kenya}

\section{By ERNeST STABLER}

A comprehensive review of Kenya's educational developments and problems since independence. Mr Stabler considers the colonial legacy, the current primary system, the harambee schools, and a variety of advanced institutions and teacher-training institutes.

The last section looks sharply at the problems Kenya must face in the coming years: a high rate of population growth and restraints imposed by an agrarian economy, among others.

Mr Stabler is Dean of Althouse College of Education at the University of Western Ontario. Written in a jargon-free style, this work reflects his wide educational experience and common sense-and his first-hand knowledge from two years with the Kenya Ministry of Education.

224 pages. With notes, bibliography, and index. $\$ 7.95$

and two books on South Africa

By Pierrevan den Berghe

\section{SOUTH AFRICA A Study in Conflict}

'One of the sharpest scrutinies of the country to have been published in recent years. His analysis of apartheid is a crushing accumulation of facts often snatched from the lap of the government.'-Book Week

381 pages. With charts, notes, appendixes, bibliography, and index. $\$ 8.95$

\section{CANEVILLE \\ The Social Structure of a South African Town}

'This book reports the results of a seven-month social anthropological study of a commercial town in South Africa's prosperous sugar belt near Durban... The result is an impressive and wellargued structural analysis of apartheid in action"-The Annals of the American Academy of Political and Social Science

286 pages. With charts, maps, bibliography, and index. $\$ 6.95$

\section{WESLEYAN UNIVERSITY PRESS}

Middletown, Connecticut 06457 


\section{GENEVA-AFRICA}

THE JOURNAL OF THE GENEVA-AFRICA INSTITUTE

Africa in time past lent the European imagination that touch of exotic adventure which its own milieu did not always provide. That time is no more. Africa today seeks her own way through difficulties and incertitudes to which no one open to her desire to meet on terms of equality can remain indifferent.

It is the wish of Geneva-Africa to be an active partner in this unconditional dialogue, and to contribute to a deeper comprehension of the problems and opportunities facing an emergent Africa.

Published twice yearly

Price per copy: Switzerland Fr. 6.-; France NF 7.50; United Kingdom 12s.; United States \$1.65; Africa NF 7.50 or $12 s$.

Price of subscription for four copies: Switzerland Fr. 22.50; France NF 27.-; United Kingdom $£ 2.5 s$.; United States $\$ 6.30$; Africa NF 27.- or £2. 5 s.

Address

2-4, ROUTE DE DRIZE, CAROUGE-GENEVA SWITZERLAND 


\section{A Historical Geography of Ghana}

\section{K. B. DICKSON}

This book describes how man has lived on and used the land of Ghana from the earliest times almost up to the present day. It has been written in the belief that the characteristic features and problems of land-use in presentday Ghana can only be fully understood with a sound knowledge of its historical geography.

£7 ros. net

\section{Industrialization in an Open Economy}

Nigeria $1945-1966$

PETER KILBY

A detailed study of how manufacturing and processing industries have developed in the largest country of West Africa, examined within its historical framework. Dr Kilby shows that the experience of Nigeria's industrialization challenges conventional development theory.

95s. net

A New Series

\section{Colonialism in Africa $1870-1960$}

\section{General Editors: PETER DUIGNAN and}

\section{H. GANN}

A four-volume collaborative history of modern Africa. The aim is to provide an up-to-date analysis of what is known about recent African history.

First volume in the series

The History and Politics of Colonialism, 1870-1914

\section{Edited by L. H. GANN and PETER DUIGNAN}

In this volume a group of leading scholars provide an authoritative account of the political history of Africa in the opening years of the colonial era.

\section{f5 net \\ U.K. prices \\ CAMBRIDGE UNIVERSITY PRESS}




\section{CAHIERS \\ D’ÉTUDES \\ AFRICAINES}

REVUE DES SCIENCES HUMAINES EN AFRIQUE NOIRE

ÉDITÉE PAR

\section{L'ÉCOLE PRATIQUE DES HAUTES ÉTUDES}

SIXIEME SECTION: SCIENCES ÉCONOMIQUES ET SOCIALES DIVISION DES AIRES CULTURELLES: CENTRE D'ÉTUDES AFRICAINES

\section{RÉDACTION ET ADMINISTRATION}

Cabiers d'Etudes Africaines, École Pratique des Hautes Études, VIe Section, Division des Aires Culturelles, 20, rue de La Baume, 75-Paris 8 . Tél.: $225-43-85$

\section{ABONNEMENT (4 numéros)}

France et zone franc $.0 .0 .60 \mathrm{~F}$ Le numéro $. \quad . \quad . \quad . \quad . \quad . \quad . \quad . \quad . \quad . \quad .15 \mathrm{~F}$

MOUTON $\& \mathrm{C}^{\mathrm{ie}}$, éditeur, 39 , avenue Philippe-Auguste, 75 -Paris $\mathrm{I}^{\circ}$ C.C.P. Paris $n^{\circ} 50-6796$ 


\title{
The Political Dilemma of Popular Education
}

\section{AN AFRICAN CASE}

\author{
David B. Abernethy
}

In striving for stable political development and rapid economic growth, the new states of Africa and Asia have justifiably placed high priority on the widespread expansion of education. This case study of universal primary education in Southern Nigeria demonstrates, however, that such expansion may create unforeseen new obstacles to modernization. Among them are the burden of the high cost of education on a developing economy, large-scale unemployment among the educated, and low morale among teachers. The author examines the various influences which contributed to Southern Nigeria's early educational history, and in a concluding section he suggests a strategy for maximizing education's contribution to political development. Stanford Studies in Comparative Politics.

Order from your bookstore, please

\section{STANFORD UNIVERSITY PRESS}

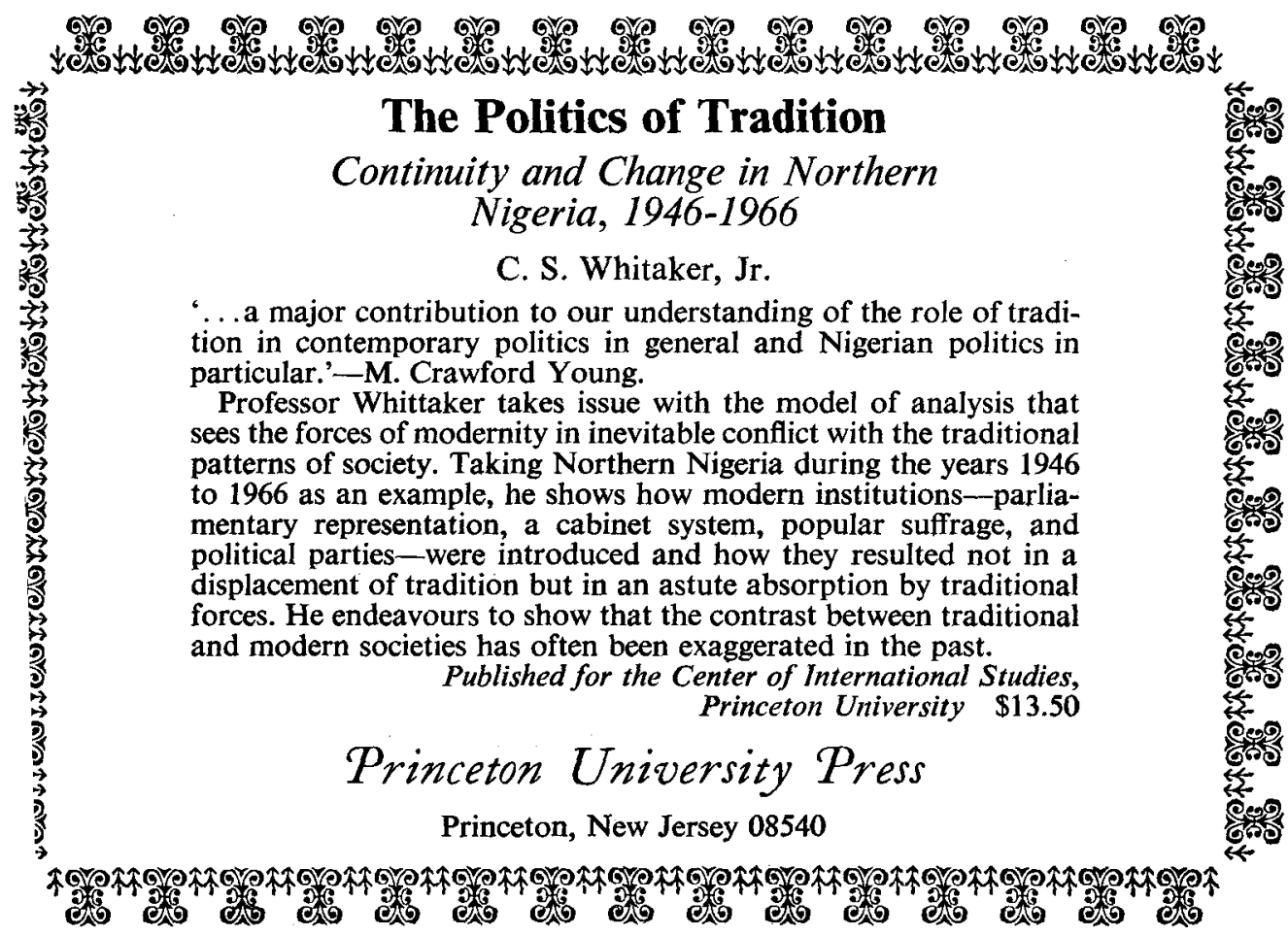

(v) 


\section{JOURNAL OF \\ COMMONWEALTH POLITIGAL STUDIES}

Vol. VII No. 3

November 1969

The Political Symbolism of the Cow in India

by Anthony Parel

The Afrikaner in Opposition, 1910-1958

by $A$. W. Stadler

Malay Participation in Commerce and Industry:

The Role of RIDA and MARA

by 7. H. Beaglehole

Reviews of Books

Annual subscription rate 55s. Single issues 22s. $6 d$.

LEIGESTER UNIVERSITY PRESS

The University, Leicester, England

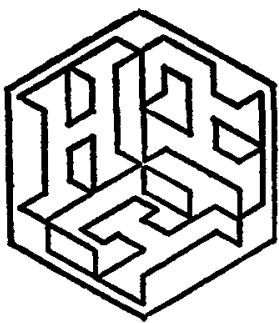

IN THE FALL 1969 ISSUE

A Special Issue

\section{ARCHITECTURE AND EDUCATION}

An illustrated issue in which architects, urban planners, educators, social critics and community organizers explore the cultural, educational and political implications of architecture, spatial design, and environment.

ARTICLES BY

James Ackerman

Colin Carewe

Aldo van Eyck

Robert Goodman

Peter Prangnell

Robert Coles

Herman Hertzberger

Maurice Smith

Giancarlo De Carlo

Shadrach Woods

\section{HARVARD EDUCATIONAL REVIEW}

13 Appian Way, Cambridge, Massachusetts 02138

Subscriptions: 1yr., \$10.00; 2yrs., \$18.00 Special Issue: $\$ 4.75$

(vi) 


\section{Educational Development in the Sudan 1898-1956}

MOHAMED OMER BESHIR

This book deals with the background and development of the Sudan's educational system, and with the influence of economic, political, and administrative factors on educational policy. It contains the first comprehensive bibliography on Sudanese education. 55/- net Oxford Studies in African Affairs

\section{The Memoirs of Babikr Bedri}

Translated from the Arabic by YOUSEF BEDRI and GEORGE SCOTT, with an introduction by P. M. HOLT

Babikr Bedri was the outstanding figure in Sudanese education until his death at 94, fifteen years ago. This book, a lively account of a Sudanese childhood nearly a century ago, is also an important historical document, because it spans the period of the Mahdist uprising in which Bedri served as a soldier in the Mahdist army. Frontispiece, 3 maps, $55 /-$ net

\section{Imperialism and Nationalism in the Sudan}

A Study in Constitutional and Political Development: 1899-1956

MUDDATHIR ABD 'AL RAHIM

The first full-scale study of the constitutional and political development of the Sudan under the Anglo-Egyptian administration of the first half of this century, examined in the context of the cultural and social revolution of the country, and based on hitherto unexplored archives and Arabic sources. 60/- net Frontispiece 63/-net Oxford Studies in African Affairs Forthcoming

\section{A History of the Upper Guinea Coast}

\section{WALTER RODNEY}

The West African Coast between the Gambia and Cape Mount has a historical, geographical, and ethnical unity despite its arbitrary partitioning between the British, French, and Portuguese in the 19th century. Dr Rodney's study of it is based on the hitherto unexploited archives in the slave trade and other forms of commerce. 5 textfigures. 50/-net Oxford Studies in African Affairs

\section{The Administration of Nigeria 1900-1960}

\section{Men, Methods, and Myths}

I. F. NICOLSON

The emphasis is on the administrators: what kind of men they were, what they tried to do, their problems, their successes and failures, and the consequences of their actions. It is an account of able, honest stewardship for the most part, although the author has made a drastic reassessment of the work of Lord Lugard. 1 map. 45/- net

\section{Modernizing Peasant Societies}

\section{A Comparative Study in Asia and Africa \\ GUY HUNTER}

Describes the modernizing process and its political, ideological, and educational background in Africa between the Sahara and the Zambesi and in India, Pakistan, and South-East Asia. 40/-net Institute of Race Relations

\section{OXFORD UNIVERSITY PRESS}




\section{THE JOURNAL OF DEVELOPMENT STUDIES}

\section{A Quarterly Journal devoted to Economic, Political and Social Development}

\begin{tabular}{lll}
\hline VOLUME 5 & JULY 1969 & NUMBER 4
\end{tabular}

Some Features of the Economic Development of Tropical Africa

ROBERT SZERSZEWSK

Allocating Foreign Aid: An Appraisal of a Self-help Model

JoHn CONLISK AND Donald Huddie

A Theoretical Note on Labour as an 'Inferior' Factor in Less Developed Countries

Uniform versus Differentiated Protected Tariffs

Michael P. TODaro

The Case for Export Subsidies

Peter Eckstetn

Paul STReeten

A Structural Approach to the Balance of Payments of a Low Income Country

Tony Killick AND R. W, DuRING

A Note on the Institute of Development Studies

Book Reviews

PUBLISHED BY FRANK CASS \& CO. LTD.

67 GREAT RUSSELL STREET, LONDON, W.C. 1

Single Issues $21 s$.

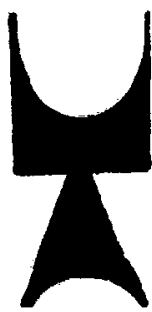

Le Mois en Afrique

\section{REVUE FRANÇAISE D'ÉTUDES POLITIQUES AFrICAINES}

DIRECTEUR: PIERRE BIARNES

REDACTEUR EN CHEF: PHILIPPE DECRAENE

\section{CHAQUE MOIS....}

Analyse les événements survenus en Afrique durant le mois écoulé.

Etudie de manière approfondie en plusieurs articles importants une grande question politique d'intérêt permanent concernant l'ensemble du continent ou une région de celui-ci.

Rend compte des principaux ouvrages, thèses, études consacrés à la politique africaine publiés durant les mois précédents.

\section{SOCIÉTÉ AFRICAINE D’ÉDITION \\ B.P. 1877, Dakar, Sénégal}

Bureau à Paris: 32 Rue de l'Échiquier, Paris (10 $)$ 


\section{THE JOURNAL OF MODERN AFRICAN STUDIES}

The Journal offers a quarterly survey of politics, economics, and related topics in contemporary Africa.

The main emphasis is upon the peoples and policies, the problems and progress of this dynamic and disparate continent; upon the many societies that are evolving rather than the essential characteristics of the old; upon the present, not on the more distant past. The best current work is sought from specialists in different academic disciplines, whose contributions can illuminate and crossfertilise one another.

The Journal seeks to promote a deeper understanding of what is happening in Africa today. It is intended for both the political scientist and the practical politician, the administrator and the advocate, the economist and the educator, the banker and the businessman, the diplomat and the technocrat, the civil servant and the nationalist leader. All have something to contribute to these pages and, it is hoped, much to learn from them.

Editorial policy avoids commitment to any political viewpoint or ideology, whether imperialism, pan-Africanism, capitalism, socialism, or nationalism. Such concepts, however, have relevance to the modern African situation, and merit serious discussion, often from several different points of view, in order that controversial issues may be fairly examined. 


\section{CAMBRIDGE U NIVERSITY PRESS}

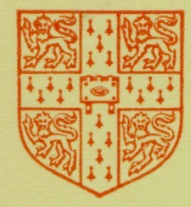

Bentley House, 200 Euston Road, London, N.W.1

American Branch: 32 East 57th Street, New York, N.Y.10022

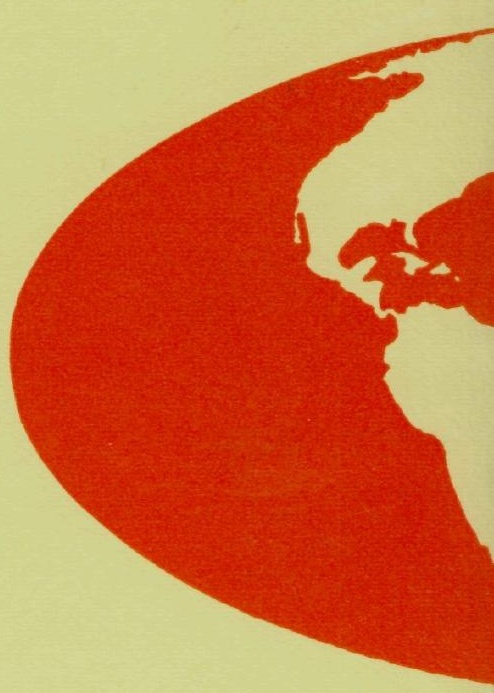

25s. net $\$ 2.75$ in U.S.A. Subscription Price 80 s. net $\$ 8.50$ in U.S.A. 